\title{
INFLUENCE OF BENZYL AMINO PURINE ON SHOOT PRODUCTION THROUGH IN VITRO SHOOT TIP CULTURE OF CUCUMBER
}

\author{
"S.M.Faisal ${ }^{1}$, Md. Shahidul Haque ${ }^{2}$ and K. M. Nasiruddin ${ }^{2}$ \\ $1=$ Former Ph.D Student and 2 = Professor, Department of Biotechnology, Bangladesh Agricultural University, \\ Mymensingh, Bangladesh. \\ *osru2002@yahoo.com (Corresponding author) \\ Received on $8^{\text {th }}$ July 2011 , accepted in revised form 15 July 2011.
}

\begin{abstract}
Multiple shoot production ability of some commercial cucumber varieties were assessed. Four varieties of cucumber such as Shila, Green Field, Shital and shahi-50 and four BAP concentrations such as 0.0, 1.0, 3.0 and $5.0 \mathrm{mg} / \mathrm{l}$ were tested against this investigation. Different cucumber varieties and BAP concentrations showed significant effects in all the parameters studied. All the varieties regenerated maximum number of explants when they were cultured on Murashige and Skoog media supplemented with BAP @ $3.00 \mathrm{mg} / \mathrm{l}$ which was followed by the BAP @ $5.00 \mathrm{mg} / \mathrm{l}$. Variety Green Field took the shortest time (6.11 days) for shoot initiation when it was cultured on BAP @ $3.00 \mathrm{mg} / \mathrm{l}$ enriched Murashige and Skoog media. Variety Green Field produced the highest number of multiple shoots regardless of BAP concentrations except control at second subculture but at third subculture all the varieties produced more than double number of multiple shoots regardless of BAP concentrations except BAP free media.
\end{abstract}

(Keywords : Multiple shoot, in vitro, shoot tip and subculture.)

\section{INTRODUCTION}

Cucumber (Cucumis sativus L.), a member of the family Cucurbitaceae, is one of the oldest vegetable crop supposed to be originate in India, between the Bay of Bengal and the Himalayas (Peirce, 1987). Cucumis sativus $\mathrm{L}$. is one cucumber species which is commercially important vegetable (Nonnecki, 1989).

The total area and production of cucumber in Bangladesh during 2003 - 04 were 13,925 ha and $25215 \mathrm{mt}$, respectively the production has increased upto $32000 \mathrm{mt}$ during the year 2006-'07 (BBS, 2008). The data indicates that total production has increased during the last few years with increased demand of cucumber. However, average yields of cucumber during 2002-'03, 2003-'04 and 2004-'05 were 4.47, 4.47 and $4.37 \mathrm{mt} / \mathrm{ha}$, respectively (BBS, 2006) which showed that the yield was declined slightly. Yield of cucumber is very low in Bangladesh compared to cucumber producing countries like China (12.24 t/ha), former USSR (7.57 t/ha), Japan (44.23 t/ha), USA (11.06 t/ha), Turkey (16.07 t/ha), Netherlands (192.50 t/ha), Spain (30.00 t/ha) (Nonnecki, 1989).
Different biotic and abiotic factors are responsible for low yield of cucumber in our country which may exert a deleterious effect on yield, marketable qualities and storabilities. Without these, the population of our country is increasing day by day but the land is decreasing. Therefore, we need to utilize the lands which are not under cultivation at present, such as, coastal zone which have high saline properties. That's why we need millions of healthy cucumber seedlings in a short period of time.

The advantages of in vitro propagation is that it offers fast multiplication rates (Mott, 1981). Chawla (2002) mentioned the significant advantages of micropropagation by which a large number of plants can be produced from a single individual in a relatively short span of time and space. The primary goals of the in vitro propagation of vegetable crops are -1) Production of large number of plantlets from the species in which plant development from seed is difficult, 2) clonal propagation of large numbers of genetically identical plantlets, 3) production of virusfree plant material and 4) crop improvement through various techniques of genetic modification (Torres, 1989). To produce disease-free plants, meristem tip 
should be cultured. Actively growing shoot tips are recommended for their culture because of their strong growth potential and low virus concentration (Chawla, 2002). Considering the discussed facts, study on disease/ virus free multiple shoot production in cucumber was undertaken. Therefore, the present study was carried out with the objectives to establish a suitable and develop a reproducible protocol for in vitro regeneration of some cucumber varieties and to asses the multiple shoot production ability of popular cucumber varieties in Bangladesh.

\section{MATERIALS AND METHODS}

The experiment was carried out at the Biotechnology Laboratory, Department of Biotechnology, Bangladesh Agricultural University (BAU), Mymensingh during June, 2005 to July, 2008. There were 2 factors in this experiment. Factor A consisted of four cucumber varieties and factor $\mathrm{B}$ consisted of four concentrations of benzyl amino purine (BAP). Four cucumber varieties such as Shila, Green Field, Shital and Shahi-50 and four BAP concentrations @ 0.0 (Control), 1.0, 3.0 and $5.0 \mathrm{mg} / \mathrm{l}$ were used. So total number of treatments were 16. Each treatment consisted of 6 test tubes/vials. The experiment was carried out in a Completely Randomized Design (CRD) with three replications. A nutrient medium for plant regeneration usually consists of organic and inorganic salts, irons, a carbon source, some vitamins and growth regulators. In this study Murashige and Skoog (1962) medium was used as basal medium for plant regeneration.

Shoot tip explants were collected from seeds of four cucuimber varieties which were germinated in vitro in several separate petridishes. For establishing the plants in the media only the tender and active growing shoot tips having $1.00-1.25 \mathrm{~cm}$ long were prepared to use as explants. To maintain aseptic condition, precautions were taken in every step of works. All inoculations and aseptic manipulations were carried out in a laminar airflow cabinet. It is usually started half an hour before use. The cabinet was wiped with $70 \%$ ethyl alcohol $\left(\mathrm{C}_{2} \mathrm{H}_{5} \mathrm{OH}\right)$ to reduce the chances of contamination. The inoculating instruments like scalpels, forceps etc. were sterilized. Other required materials like distilled water, hard papers etc. were sterilized by autoclave. Hands were properly washed with soap before starting work in laminar airflow cabinet. During operation, hands and cabinet base were rubbed with $70 \%$ ethyl alcohol frequently for maintaining clean condition. To obtain possible contamination free condition in clean bench proper care was taken during explant preparation. Shoot tips were prepared inside the laminar airflow cabinet using a fine sterile forcep and scalpel. The excised shoot tips were then inoculated on to the culture test tubes/vials containing various concentrations of BAP for in vitro multiple shoot regeneration. The physical conditions for growth and development of cultures were maintained at the temperature of $25 \pm 1^{\circ} \mathrm{C}$ and a light intensity of 20003000 lux provided by fluorescent tube. The photoperiod was maintained at 16 hours light and 8 hours dark $(16 \mathrm{~L} / 8 \mathrm{D})$ and the relative humidity was $60-70 \%$.

Successful shoot formation became evident when small green fresh leaves began to emerge. Developed tiny leaves, were transferred into fresh media containing the same hormonal concentration for further proliferation and development of shoots. First subculture was carried out at 25 days after shoot (DAS) initiation. Second and third subcultures were carried out at 50 and 75 DAS initiation, respectively. Multiple shoots were counted at second and third subculture only. The regenerated multiple shoots were carefully removed from the culture tubes/vials and placed on a sterile hard paper. Each shoot was cut from the basal end and was transferred to new media containing concentrations of BAP for further multiple shoot induction.

Data on number of explants regenerated, days to shoot initiation, percentage of explants regenerated, number of multiple shoots per explant at scond and third subculture were recorded. The data were analyzed using MSTAT-C statistical software. Differences among the means were compared following Duncan's Multiple Range Test (DMRT) at $5 \%$ level of significance.

\section{RESULTS AND DISCUSSION}

\section{Influence of varieties}

The effect of varieties have been presented in Table 1. There were no significant difference among the varieties on number and percentage of explants regeneration. Maximum number of explants regeneration was observed in variety Green Field (3.82) followed by Shital (3.77). Shahi-50 regenerated minimum number (3.65) of explants. The highest (63.74) and the lowest (60.96) percentage of explants regeneration were observed in Green Field and Shahi-50, respectively. Plate 1 shows the explant regeneration of Shital after 7 days of explant inoculation.

Days required to shoot initiation and number of shoots per explant at second and third subculture was differed significantly by varieties. Variety Green Field was superior compared with other varieties. 
Shahi-50 took maximum time (6.83 days) for shoot initiation which was statistically identical with Shila (6.74 days) but significantly differed from Shital (5.47 days) and Green Field (4.72 days). The highest (4.22 and 12.50, respectively) and the lowest number (3.10 and 8.51, respectively) of multiple shoot production was produced by Green Field and Shahi50, respectively (Fig. 1). Shila and Shital showed the moderate performance in this regard. Mohiuddin et al. (1997) found that distal cotyledon and hypocotyl explants were not responsive while only poor shoot regeneration observed in proximal cotyledon and hypocotyl explants of all cucumber cultivars which was due to use of proximal cotyledon and hypocotyls explants. Chawla (2002) reported that actively growing shoot tips have strong growth potential. He also reported that shoot tips have sufficient endogenous cytokinin which support growth and development. Whener and Locy (1981) obtained the highest percent $(53 \%)$ of shoots from the line P1 279463 through using cotyledon explants after 45 days of culture. But in present investigation the highest number of multiple shoots obtained after 50 days from shoot initiation which partially agreed with Whener and Locy (1981).

There may be very few studies about effect of varieties on in vitro regeneration and multiple shoot production of cucumber in Bangladesh as well as in other countries. So, informations on this aspect are not available.

\section{Influence of BAP}

Significant effect of BAP was found in all the parameters studied (Table 2). Shoot initiated directly from explant without callus phase. The number and percentages of regenerating explants increased widely and progressively with higher concentration of BAP except $5 \mathrm{mg} / \mathrm{l}$. This concentration showed the inferior performance over it's previous concentration (3 $\mathrm{mg} / \mathrm{l} \mathrm{BAP}$ ) in all the parameters but it was statistically identical with same concentration in respect of number and percentage of explant regeneration.

These results suggest that $3 \mathrm{mg} / \mathrm{l}$ of BAP was the best among the concentrations studied. Msikita et al. (1990) investigated an experiment to see the effects of various concentration of BAP (2.0, 3.0, 4.0 and 5.0 $\mathrm{mg}$ litre $\left.^{-1}\right)$ and NAA (0.0, 0.1 .0 .2 and $\left.0.3 \mathrm{mg} / \mathrm{l}\right)$ towards shoot regeneration from cotyledonary explants of cucumber. They observed a maximum of $50 \%$ shoot regeneration from cotyledonary explants in MS media fortified with either $2 \mathrm{mg}$ BAP and 0.3 $\mathrm{mg} \mathrm{NAA} / \mathrm{l}$ or $4 \mathrm{mg} \mathrm{BAP}$ and $0.3 \mathrm{mg}$ NAA/litre.
Maximum percent $(91.20 \%)$ shoot regeneration was observed when $3 \mathrm{mg} / \mathrm{l}$ BAP was supplemented in MS medium which was statistically similar with the highest concentration but significantly different $(69.58 \%)$ from the lowest concentration.

Multiple shoots were produced in all treatments except control. The second highest concentration of BAP (3 $\mathrm{mg} / \mathrm{l}$ ) was superior to all other tested concentrations regarding production of number of shoots per explants at both subcultures (plate 2 and plate 3). Using 1.5 and $2.0 \mathrm{mg} / \mathrm{l} \mathrm{BA}$ supplemented media Shibli and Ajlouni (1996) obtained maximum number (2.0) of shoots from one nodal explant after 30 days of culture in cucumber. In their investigation there were scope to count multiple shoots after 50 or 75 days after culture. Sultana and Miah (2003) investigated an experiment and obtained maximum number of multiple shoots/culture from shoot tip and nodal explant (4.25 and 5.00, respectively) when MS media supplemented with $2.0 \mathrm{mg} / \mathrm{l}$ of BA. But number of shoots/culture were declined (3.95 and 4.40, respectively) when 2.5 $\mathrm{mg} / \mathrm{l}$ of BA was used.

In this investigation although bitter gourd is different from the cucumber, they share the same family, that is Cucurbitaceae. So, these findings could be considered. Msikita et al. (1990) obtained the best result regarding multiple shoot production by using modified MS media supplemented with $2 \mathrm{mg}$ BAP per liter. He also mentioned that shoot production was significantly reduced by increasing BAP concentration from 2 to 5 $\mathrm{mg}$ litre $^{-1}$. This finding supports the results of present investigation, although in present investigation multiple shoot production was reduced from $5 \mathrm{mg} / \mathrm{l}$ of BAP supplemented MS medium.

From above discussions, it was found that higher concentrations of BAP are not suitable for obtaining large scale multiple shoots. Benzyl Amino Purine is generally supplemented to a culture medium to stimulate cell division, to induce shoot formation and axillary shoot proliferation and to inhibit root formation (Torres, 1989). Cytokinin enriched medium reinforces regenerative responses like somatic embryogenesis, adventitious shoot formation in callus (indirectly) or directly from explants and auxillary shoot proliferation, depending on the source of explants and the genotypes (Narayanaswamy, 1994). 
Table 1. Shoot regeneration and multiple shoot production from shoot tips of cucumber as influenced by Varieties

\begin{tabular}{lccc}
\hline Treatments & $\begin{array}{c}\text { Number of } \\
\text { explants } \\
\text { regenerated }\end{array}$ & $\begin{array}{c}\text { Days to } \\
\text { shoot } \\
\text { initiation }\end{array}$ & $\begin{array}{c}\text { \% of } \\
\text { explants } \\
\text { regenerated }\end{array}$ \\
\hline Variety & $3.66 \mathrm{a}$ & $6.74 \mathrm{a}$ & $61.07 \mathrm{a}$ \\
Shila & $3.82 \mathrm{a}$ & $4.72 \mathrm{c}$ & $63.74 \mathrm{a}$ \\
GF & $3.77 \mathrm{a}$ & $5.47 \mathrm{~b}$ & $62.92 \mathrm{a}$ \\
Shital & $3.65 \mathrm{a}$ & $6.83 \mathrm{a}$ & $60.96 \mathrm{a}$ \\
Shahi-50 & & & \\
\hline
\end{tabular}

Means in a column followed by uncommon letter (s) varied significantly at $5 \%$ level of significance

Table 2. Shoot regeneration and multiple shoot production from shoot tips of cucumber as influenced by different concentrations of BAP

\begin{tabular}{lccccc}
\hline Treatments & $\begin{array}{c}\text { Number of } \\
\text { explants } \\
\text { regenerated }\end{array}$ & $\begin{array}{c}\text { Days to } \\
\text { shoot } \\
\text { initiation }\end{array}$ & $\begin{array}{c}\text { \% of } \\
\text { explants } \\
\text { regenerated }\end{array}$ & $\begin{array}{c}\text { Number of } \\
\text { shoots/explant } \\
\text { at } \mathbf{2}^{\text {nd }} \text { subculture }\end{array}$ & $\begin{array}{c}\text { Number of } \\
\text { shoots/explant } \\
\text { at } \mathbf{3}^{\text {rd }} \text { subculture }\end{array}$ \\
\hline Concentration of BAP $(\mathbf{m g} / \mathbf{l})$ & & & & \\
\hline 0.00 & $0.00 \mathrm{c}$ & $0.00 \mathrm{c}$ & $00.00 \mathrm{c}$ & $0.00 \mathrm{~d}$ & $00.00 \mathrm{~d}$ \\
1.00 & $4.17 \mathrm{~b}$ & $8.05 \mathrm{a}$ & $69.58 \mathrm{~b}$ & $4.07 \mathrm{c}$ & $12.04 \mathrm{c}$ \\
3.00 & $5.47 \mathrm{a}$ & $7.78 \mathrm{~b}$ & $91.20 \mathrm{a}$ & $5.59 \mathrm{a}$ & $15.14 \mathrm{a}$ \\
5.00 & $5.27 \mathrm{a}$ & $7.79 \mathrm{a}$ & $87.88 \mathrm{a}$ & $5.10 \mathrm{~b}$ & $14.02 \mathrm{~b}$ \\
\hline
\end{tabular}

Means in a column followed by uncommon letter (s) varied significantly at $5 \%$ level of significance

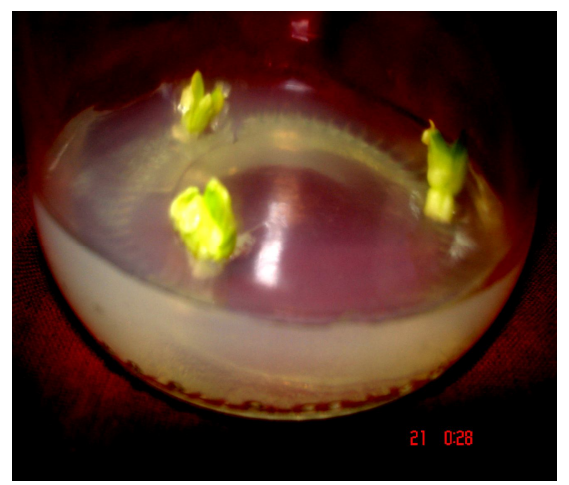

Plate 1. Shoot regeneration from shoot tip explant of cucumber (var. Shital) in MS medium 


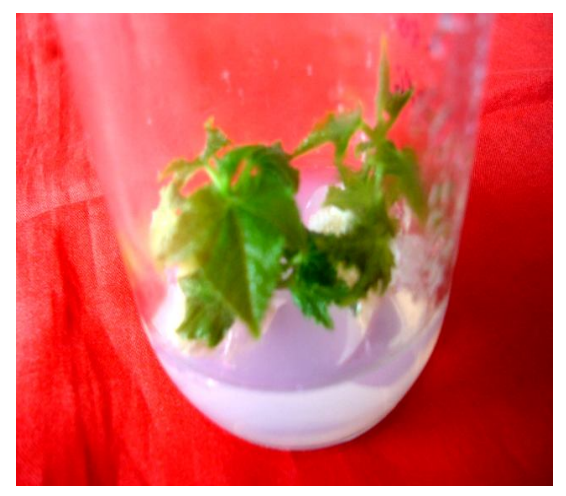

Plate 2. Multiple shoots of var. Shahi-50 in MS medium supplemented with $3.0 \mathrm{mg} / \mathrm{l} \mathrm{BAP}$

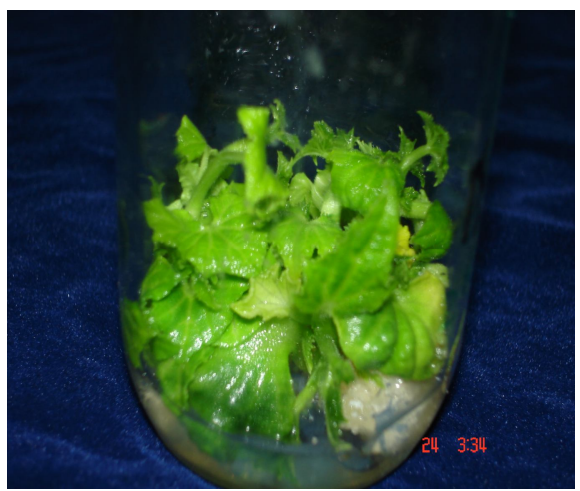

Plate 3. Multiple shoots of var. Shital in MS medium supplemented with $3.0 \mathrm{mg} / \mathrm{l} \mathrm{BAP}$

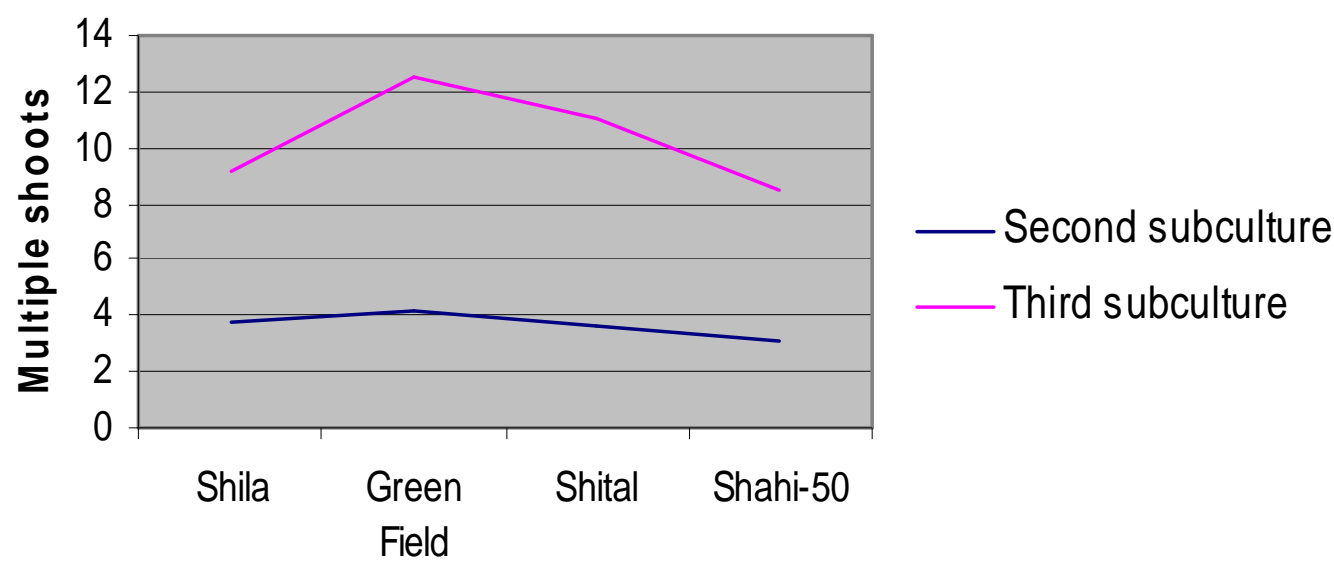

\section{Variety}

Figure. 1. Effect of variety on multiple shoot production in cucumber 
Interaction between variety and BAP

It was found that varieties significantly interacted with BAP in all the parameters studied (Table 3). None of the varieties regenerated shoot on MS medium without BAP (Fig. 2). All the varieties regenerated maximum number of explants when they were cultured on MS media supplemented with the second highest BAP concentration $(3 \mathrm{mg} / \mathrm{l})$ which was followed by the highest conc $(5 \mathrm{mg} / \mathrm{l})$ of BAP. The same result was also observed in the percentage of explant regenerated (Fig. 3).

Variety Green field required the shortest time (6.11 days) for shoot initiation when it was cultured on $3.0 \mathrm{mg} / \mathrm{l} \mathrm{BAP}$ enriched MS medium and this concentration of BAP was superior to the other tested concentrations irrespective of varieties Maximum numbers of multiple shoots were produced by Green Field regardless of BAP concentrations except control at second subculture.

All the varieties produced more than double multiple shoots at all concentrations except control media at third subculture compared to second subculture. There was a positive relation among varieties and BAP concentrations upto $3.0 \mathrm{mg} / \mathrm{l}$ regarding multiple shoot production at both subcultures, thereafter the multiple shoot formation declined at the highest BAP concentration (5.0 $\mathrm{mg} / \mathrm{l})$.

Table 3. Shoot regeneration and multiple shoot production from shoot tips of cucumber as influenced by varieties and different BAP concentrations.

\begin{tabular}{lcccc}
\hline Variety & $\begin{array}{c}\text { BAP } \\
\text { concentration } \\
(\mathbf{m g} / \mathbf{l})\end{array}$ & $\begin{array}{c}\text { Days to shoot } \\
\text { initiation }\end{array}$ & $\begin{array}{c}\text { Number of } \\
\text { shoots/explant } \\
\text { at } \mathbf{2}^{\text {nd }} \text { subculture }\end{array}$ & $\begin{array}{c}\text { Number of } \\
\text { shoots/explant } \\
\text { at } \mathbf{3}^{\text {rd }} \text { subculture }\end{array}$ \\
\hline Shila & 0.00 & $0.00 \mathrm{f}$ & $0.01 \mathrm{~g}$ & $00.00 \mathrm{j}$ \\
& 1.00 & $9.02 \mathrm{a}$ & $4.64 \mathrm{de}$ & $11.18 \mathrm{~h}$ \\
& 3.00 & $8.91 \mathrm{a}$ & $5.50 \mathrm{c}$ & $13.23 \mathrm{e}$ \\
& 5.00 & $9.03 \mathrm{a}$ & $4.84 \mathrm{~d}$ & $12.18 \mathrm{fg}$ \\
\hline \multirow{3}{*}{ Green Field } & 0.00 & $0.00 \mathrm{f}$ & $0.00 \mathrm{~g}$ & $00.00 \mathrm{j}$ \\
& 1.00 & $6.49 \mathrm{~d}$ & $4.40 \mathrm{de}$ & $14.27 \mathrm{~d}$ \\
& 3.00 & $6.11 \mathrm{e}$ & $6.52 \mathrm{a}$ & $19.05 \mathrm{a}$ \\
& 5.00 & $6.29 \mathrm{de}$ & $5.99 \mathrm{ab}$ & $16.68 \mathrm{~b}$ \\
\hline \multirow{3}{*}{ Shital } & 0.00 & $0.00 \mathrm{f}$ & $0.00 \mathrm{~g}$ & $00.00 \mathrm{j}$ \\
& 1.00 & $7.52 \mathrm{~b}$ & $3.73 \mathrm{f}$ & $12.89 \mathrm{ef}$ \\
& 3.00 & $7.12 \mathrm{c}$ & $5.71 \mathrm{bc}$ & $15.52 \mathrm{c}$ \\
& 5.00 & $7.25 \mathrm{c}$ & $5.31 \mathrm{c}$ & $15.75 \mathrm{c}$ \\
\hline
\end{tabular}

Means in a column followed by uncommon letter (s) varied significantly at 5\% level of significance 


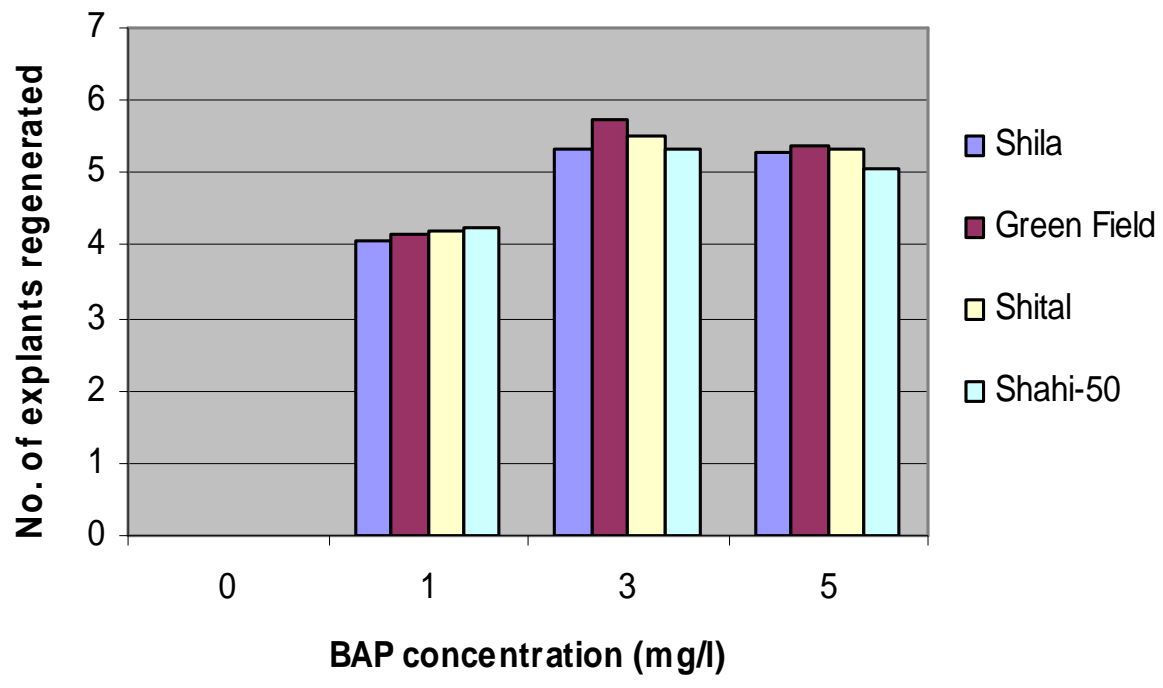

Figure 2. No. of explants regenerated as affected by varieties and BAP concentrations

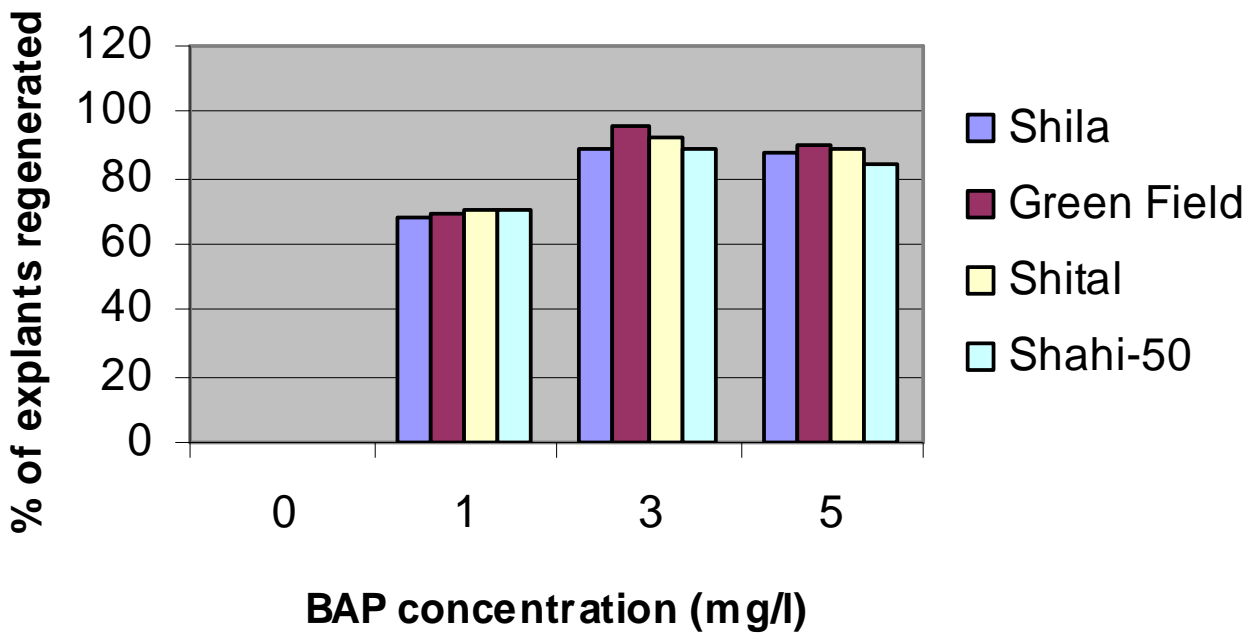

Figure 3. Combined effect of variety and BAP on percentage of explants regenerated

\section{ACKNOWLEDGEMENTS}

I have accomplished this research work under the " Ph.D. Scholarship" program of Horticulture Research Centre under Bangladesh Agricultural Research institute (BARI). I am grateful to BARI. I am also grateful to "the ministry of Science and Information and Communication technology" of the Government of Bangladesh for providing financial support during Ph.D. study. 


\section{REFERENCES}

1. BBS. (2008). Statistical pocket book of Bangladesh. Bangladesh Bureau of statistics, Ministry of Planning, Government of the People's Republic of Bangladesh, Dhaka, Bangladesh. 209 p.

2. BBS. June, 2006. Monthly statistical bulletinBangladesh. Bangladesh Bureau of statistics.

3. Chawla, H.S. 2002. Introduction to Plant Biotechnology. Oxford \& IBH publishing Co. Pvt. Ltd., 66 Janapath, New Delhi 110001, India. pp 40-42.

4. Mohiuddin, A.K.M., Chowdhury, M.K.U., Abdullah, Z.C. and Napis, S. 1997. Influence of silver nitrate (ethylene inhibitor) on cucumber in vitro shoot regeneration. Plant Cell, Tissue and Organ Culture. 51: 75-78.

5. Mott, R.L. 1981. Trees, In: Conger, B.V. (ed.), Cloning Agricultural Plants via in vitro Techniques. CRC Press, Boca Ratan, pp. 217254.

6. Msikita, W., Skirvin, R.M., Juvik, J.A., Splittstoesser, W.E. and Ali, N. 1990. Regeneration and flowering in vitro of 'Burpless Hybrid' cucumber cultured from excised seed. HortScience. 25(4): 474-477.
7. Murashige, T. and Skoog, F. 1962. A revised medium for rapid growth and bioassays with tobacco tissue cultures. Physiol. Plant. 15: 473-497.

8. Narayanaswamy, S. 1994. Plant cell and tissue culture. Tata McGraw-Hill Publishing Company Limited, New Delhi 110002, India. 1-93 pp.

9. Nonnecki, I.L. 1989. Vegetable Production.. An AVI book, Van Nostrand Reinhold, 115 Fifth Avenue, New York 10003, USA. pp. 509-526.

10. Peirce,L.C.1987. Vegetables:characteristics, production and marketing. John Wiley and Sons, USA. pp. 357-366.

11. Shibli, R.A. and Ajlouni, M.A. 1996. In vitro propagation and Ex vitro acclimatization of 'Sahara $\mathrm{F}_{1}$ ' cucumber (Cucumis sativus L.). Plant Tissue Cult. 6 (2): 95-98.

12. Torres, K.C. 1989. Tissue Culture Techniques for Horticultural Crops. An AVI book, Van Nostrand Reinhold, 115 Fifth Avenue, Newyork 10003, USA. pp 66-69.

13. Wehner, T.C. and Locy, R.D. 1981. In vitro adventitious shoot and root formation of cultivars and lines of Cucumis sativus L. HortScience. 16(6): 759-760. 